\title{
A Cost-Benefit Analysis of China’s Trade Relations With Sub-Saharan Africa
}

\author{
Ephraim Okoro, Philemon Oyewole \\ Howard University, Washington D.C., USA
}

\begin{abstract}
Trade and economic relations between China and Africa have a protracted history and have developed incrementally over the course of time. Consequently, increasing numbers of Chinese businesses and entrepreneurs have sought partnerships with African companies with the aim of establishing strategic partnerships, collaborations, and joint ventures. In recent years, these Sino-African trading relations have been the subject of consistent debate and scrutiny, attracting positive and negative analyses from scholars and practitioners across disciplines. Some studies questioned China's motives in Africa's markets, and others viewed with suspicion the structure of Sino-Africa's bilateral trading engagements. Conducting an extensive literature survey of related sources and employing content analysis of recent and current data (2000-2009), the paper examined institutional and academic publications pertaining to Sino-African relationship. It determines imbalance in the structure of Sino-African bilateral trade, negative impact on domestic economic development, and competitive disadvantage in African marketplaces. Policy implications of these findings were provided as well as recommendations for mutual trade benefits and global strategic investments.
\end{abstract}

Keywords: development, globalization, bilateral-trade, economy, Sub-Saharan Africa, China

\section{Introduction}

In the wake of globalization, international production and consumption by multinational corporations have continued to grow and domestic businesses have sought different strategic modes of entry into foreign markets. Studies (Rotberg, 2008; Broadman, 2007) indicate that national economies have been integrated and corporations are competing in a global scale for sustainable growth and profitability. The international market has expanded and has grown increasingly competitive to the extent that developed and developing countries are identifying new strategies to advance their business opportunities. African countries and their trading partners are taking advantage of globalization by encouraging business cooperation, investments, joint ventures, and economic interdependencies. Anshan (2006), Bhargava (2006), and Gyimah-Boadi (2004) explained that the economic environment in Africa has shown a high growth rate for the past decades, and has attracted foreign trade and investment opportunities.

Ephraim Okoro, Assistant Professor, Department of Marketing, Howard University.

Philemon Oyewole, Professor, Department of Marketing, Howard University.

Correspondence concerning this article should be addressed to Ephraim Okoro, Department of Marketing, Howard University, 2600-6th Street, NW, Washington, D.C. 20059, 202-806-1545. E-mail: eaokoro@howard.edu. 
With a land mass of approximately 30,328,662 square kilometers, Africa is the second largest continent in the world. It depends mainly on agriculture and natural resources for employment and on exports of raw material and crude oil to sustain its growing economy. Over the years, African countries have attracted trade and exports from many countries, especially the United States, China, and the United Kingdom. Foreign direct investment is concentrated on minerals, mining, and food processing, and many African countries have focused on tourism, infrastructure development, and service sectors (Corporate Council on Africa, 2001). Restructuring or privatization opened up large portions of Africa's previously state-run entities to competition with domestic and foreign organizations (The World Bank, 2008; Taylor, 2009). This new policy direction has impacted domestic economy-improved production of goods and services, efficient delivery services, and availability of essential materials.

The increasing presence of China in many parts of Africa has continued to be viewed with mixed feelings by researchers and world organizations. This paper conducts a cost-benefit analysis of Sino-Africa trading partnerships, with a focus on the Sub-Saharan region. It specifically explores China's growing business interest in the region. Further, recent studies (Robert, 2008; Wines, 2007; Tull, 2006) have raised questions regarding the increasing Chinese presence in many African markets as well as the impact their presence and products might have on domestic economic development. In light of the preceding background, this paper attempts to identify positive and negative consequences associated with China's trade expansion into African markets. Other studies (Boardman, 2007; Rotberg, 2009) noted that China's exports to Africa have increased dramatically since the beginning of the decade. It was also estimated that over 750,000 Chinese were engaged in various forms of business and marketing activities in Africa (French \& Polgreen, 2007b; Taylor, 2009).

This study is guided by the following specific questions: (1) Whether the bilateral trade between China and sub-Saharan African countries is mutually beneficial; (2) Whether the alleged low-cost Chinese goods and services is impacting African domestic businesses; (3) Whether Chinese business models is placing domestic entrepreneurs in a competitive disadvantage; and (4) Whether there is equity in the use of human resources in the labor markets.

\section{Literature Review}

Comparative and critical studies on China's business presence in sub-Saharan Africa have provided strikingly divergent conclusions. Some of the authors differed significantly in their analyses of the costs associated with China's presence in Africa (Taylor, 2009; Sylvanus, 2007). Others were consistent in their views regarding trade and investment benefits to Africa (Rotberg, 2008; Broadman, 2007). Earlier studies viewed the objectives behind Sino-African bilateral trade as lopsided, impacting negatively on domestic economic development of Africa (Spring \& McDade, 1998; Anshan, 2006). Increasingly, there appears to be consensus among recent studies that China's trade expansion into the sub-Saharan region was largely driven by exploitation of natural resources, raw materials, and energy sources to boost its economic growth and export markets (Taylor, 2009; Spring \& Jao, 2008). Rotberg (2008) concurs that China’s businesses in the sub-Saharan Africa is a strategic quest for targeted or specific primary resources that can be found in the soils to support its expanded industrial base. Coincidentally, it appears that the economic circumstance in sub-Saharan Africa welcomes Chinese insatiable appetite for raw materials. China, therefore, not only uses Africa's raw materials, crude oil, or 
unprocessed substances of the subsoil, and offshore drilling, but it commits to long term infrastructural and financial investments, thereby expanding and sustaining Africa's economic capacity.

In more recent years, however, the perception of several authors (Devarajan \& Holmgren, 2001; Center for Africa Studies of Peking University, 2005; Chan-Fishell, 2007) and the international institutions is that the accelerating developments in the Sino-African relationship occurred after a dormant period that exposed new and potentially unsettling Chinese ambitions in the sub-African region. China has promoted cooperation with Africa in various phases of economic and political development endeavors. For example, Sino-African presidents have exchanged state visits for decades. Heads of States of the countries in the sub-Saharan Africa paid thirty-three visits to China in the 1970s and fifty-one in the 1980s (Rotberg, 2008; Taylor, 2009). Similarly, Chinese leaders visited thirty-three African countries over the same periods.

Against this background, there is no doubt that China has become Africa's second most important strategic trading partner, ahead of the United Kingdom, and closely following the United States. The People's Daily (2007) estimated Sino-African trading and investment at \$ 55.5 billionin 2006. Economic studies (Rudra, 2008; Spring, 2008) on the surge of China's businesses in Africa show that Chinese entrepreneurs believe they were providing economic and financial support to the economies in Africa. As Lyman (2005) stated, many Chinese intellectuals and entrepreneurs were under the impression that their investments in Africa were designed to support Africa's economic and financial situations, and to improve the quality of life of Africans. On the contrary, development researchers and political analysts (Gyimah-Boadi, 2004; Bhargave, 2006) indicate that Africans are suspicious of China's presence, and that anti-Chinese sentiments have grown increasingly widespread in many African countries, such as Nigeria, Zambia, Ghana, and South Africa.

Taylor (2009) noted that it would be exceedingly difficult to overestimate the importance of Africa to China's economic development in the twenty-first century competitive global business environment. Consistent with other authors, Broadman (2007) stressed that African's negative sentiments were triggered by the increasing exportation of inferior and low cost goods, labor abuses, undercutting of domestic industries, and the violation of basic human rights. Lyman (2005) and Ngomba (2007) explained that Africa's leaders were attracted by the "unconditional loans and infrastructure developments" and other benefits offered by the Chinese governments. These unconditional business and economic incentives impressed African leaders, and consequently swayed them from seemingly valid organizations and countries who demanded accountable, transparent, and ethical business partnerships. An analytical study by Rudra (2008) concluded that Chinese involvement in Africa is widely viewed as domination, dressed up as "globalization", which would be detrimental to the autonomy of China in the near future.

A wide range of other critical studies provide mixed perspectives on China's global marketing ventures and motives, especially in Africa. Some argue that China's engagement in the developing nations of Africa has a hidden agenda designed to exploit through direct investments and joint ventures (Stiglitz, 2003; Rotberg, 2008; Taylor, 2009). Shelton (2005) pointed out that a "Forum on China and Africa Cooperation (FOCAC)" was introduced to Africa leaders in 2000, which attracted nearly 48 active memberships. Zafar (2007) noted that Chinese Foreign Direct Investment (FDI) alone in the sub-Saharan Africa amounted to nearly \$ 1 billion in 2006, and that by the year 2007, China had committed a total of \$ 8.1 billion to numerous development projects in Nigeria, Angola, and Mozambique. Furthermore, research by Lyman (2005) and Roughmeen (2006) pointed out that the growing 
expansion of Chinese national oil companies into Africa's oil markets was evaluated as the aspect of Sino-Africa trade and investment relations that was of most concern to both Africans and global organizations.

Zhou (2008), Chinese Ambassador to the United States, emphasized China's increased interests in Africa's huge market potential, its significance in energy security, as well as its collective role in strategic world affairs. He also acknowledged Africa's prominent position in the international community, stressing that to strengthen unity with Africa is a critical part of China's independent foreign policy of peace. While Zafar (2007) contended that Africa could potentially face marginalization from the global economy because of China's dominant presence, Roughmeen (2006) stressed that China's presence in Africa could provide a model for lower-technical industrial development, stimulating the spring-off of manufacturing, or establish local investment in the continent. Conversely, other authors (Chan-Fishel, 2007; Taylor, 2009) maintained that China's projects have caused environmental degradation in sub-Saharan Africa, creatinig unhealthy living conditions for the people. Gong (2007) and Spring and Jiao (2008) described the working conditions for Africans in Chinese projects as extremely difficult and unacceptable.

Regarding type and structures of Chinese businesses in Africa, studies (The World Bank, 2007; Broadman, 2007; Rotberg, 2008) identified owners of small and medium size formal sector businesses, export-import agents and wholesalers, informal sector hawkers and retailers, and state corporations. Alden (2007) categorized the many Chinese entrepreneurs in Africa as a combination of “capitalists, comrades, and carpet-baggers”, listed three separate groups of Chinese migration to Africa in recent years. These included laid-off workers by downsizing Chinese businesses, displaced workers by large construction projects, and entrepreneurs who are navigating different parts of Africa for products and services.

\section{Study Methodology}

Data for this study was gathered from past and current publications (Morrison, 2007; Mwega \& Taylor; 2009; Broadman, 2007) and from The World Bank’s “Development Indicators” and Annual Reports (World Bank, 2006, 2007, 2008). Content analysis of these publications was conducted to evaluate costs and benefits associated with Sino-African bilateral and strategic partnerships. Tables of various transactions over different periods were analyzed, compared, and contrasted to determine transaction equity, scope of trade, and process objectivity. The analysis assessed differing authors' views about China's impact on domestic economy, unemployment, and the validity of contradictory claims of resource exploitation, and dumping.

\section{Findings}

Table 1 indicates the total Africa's imports from China (2004-2006). With the exception of South Africa, whose industrial economy is fully developed, China's main African imports are derived from oil-producing sub-Saharan countries. Studies (Spring \& McDade, 1998; Spring, 2008; Wang, 2007) revealed that the growing interest of China's national oil companies in Africa, especially in the sub-Saharan region, is the significant part of Sino-African trade and investment relations that have triggered serious concerns to researchers and international establishments. In addition to oil as a major and compelling Chinese economic interest in Africa, the authors argued that China is aggressively looking for copper, bauxite, uranium, aluminum, manganese, iron ore, and other natural resources that are available (Lyman, 2005; Roughneen, 2006). Further, there were resentments that 
China's growing interest in oil extraction and energy supplies and procurement from the sub-Saharan Africa would present serious economic challenges to the rest of the world in the near future. Their studies indicate that approximately 70 percent of African oil is exported to China (Anshan, 2006; Taylor, 2009).

Table 1

Top Five African Sources of Chinese Imports, 2004-2006 (in US \$ Millions)

\begin{tabular}{lrrr}
\hline Countries & \multicolumn{1}{c}{2004} & 2005 & 2006 \\
\hline Africa total & $15,640.9$ & $21,114.1$ & $28,767.6$ \\
Angola & $4,717.7$ & $6,580.7$ & $10,930.9$ \\
South Africa & $2,955.3$ & $3,443.6$ & $4,095.3$ \\
Congo-Brazzaville & $1,568.9$ & $2,278.0$ & $2,784.6$ \\
Equatorial Guinea & 995.3 & $1,486.1$ & $2,537.6$ \\
Sudan & $1,705.5$ & $2,614.7$ & $1,941.4$ \\
\hline
\end{tabular}

Note. Source: Morrison (2007).

Table 2 provides the structure of Chinese business ownership in Africa, ranging from state-owned businesses and corporations to individual retailers and entrepreneurs. In determining levels of businesses, this table classified them into ownership, range of capital, number of workers, business types, time/duration, and market strategies adopted in Africa. It also indicates that there were more informal-sector Chinese entrepreneurs who sell apparels and garments, and competing head-on with African domestic enterprises. These informal-private businesses were self-employed, engaged in retail and wholesale distribution, with operating capital within the range of $\$ 5,000$. Specific strategies were to compete in local and rural communities, employing family members, and selling at very low prices.

Table 2

Examples of Types and Scope of Chinese Businesses and Entrepreneurs in Africa

\begin{tabular}{|l|l|l|l|l|l|l|l|}
\hline Example & Level & Ownership & Business sec/type & Capital range & $\begin{array}{l}\text { Number and type of } \\
\text { workers }\end{array}$ & Time-frame & Strategy \\
\hline SinoHydo & Large & Formal & Energy/construct & $\$ 1 \mathrm{~m}-5 \mathrm{bn}$ & $500-1,500$ Chinese & Long & State-support \\
\hline Huawei Tech. & Large & Private/formal & Telecommun & $\$ 1-200 \mathrm{~m}$ & $100-500$ Chinese & Long & Global \\
\hline $\begin{array}{l}\text { Zhogken farm } \\
\text { Mrade Co. in } \\
\text { Nigeria }\end{array}$ & Medium & Private/formal & Internatinal trade & $\$ 1-50 \mathrm{k}$ & $5-25$ Chin/Afri. & Long & $\begin{array}{l}\text { Enterprise } \\
\text { assoc }\end{array}$ \\
\hline $\begin{array}{l}\text { Baiho shops in } \\
\text { CapeVerde }\end{array}$ & Small & Private/formal & $\begin{array}{l}\text { Fixed location } \\
\text { retail }\end{array}$ & $\$ 5-10 \mathrm{k}$ & $1-25$ Chinese family & Medium & $\begin{array}{l}\text { Local } \\
\text { community }\end{array}$ \\
\hline $\begin{array}{l}\text { Whole-sale In } \\
\text { Johnasburg }\end{array}$ & Medium & Private/informal & Wholesaler & $\$ 5-10 \mathrm{k}$ & Selfemployed & Long & $\begin{array}{l}\text { Local } \\
\text { community }\end{array}$ \\
\hline Hawkers/retail & Small & Private/informal & Retail & $>\$ 5 \mathrm{k}$ & Selfemployed & Long & $\begin{array}{l}\text { Family } \\
\text { network }\end{array}$ \\
\hline Vendors/retail & Small & Private/informal & Retail & $>\$ 5 \mathrm{k}$ & Selfemployed & Long & $\begin{array}{l}\text { Family } \\
\text { network }\end{array}$ \\
\hline
\end{tabular}

Note. Source: Spring and Jiao (2008).

Table 3 shows exports and imports patterns of selected African countries that traded with China in recent years. The original data set ranged from 1998 to 2006, but the table shows 1998, 2002 and 2006 when most trading transactions occurred. Imports from China by African countries started to accelerate in 2002, and increased rapidly by 2006. African countries imports from China were higher than exports, except Angola and 
Sudan, who shipped large quantities of oil to China. The table demonstrates that exports (mainly copper and minerals) by Zambia rose in 2006. Evidently, the tables indicate that China exported large quantities of goods into African markets. Studies (Broadman, 2007; Spring \& Jiao, 2008; Rudra, 2008) revealed that the strategy was toward Africa's dependency on Chinese imports to sustain its economic and political viability.

Table 3

Exports From Selected African Countries to China, and Imports From China to Selected African Countries (in Millions of US \$)

\begin{tabular}{|c|c|c|c|c|c|c|}
\hline \multirow{2}{*}{ Country } & \multicolumn{2}{|c|}{1998} & \multicolumn{2}{|c|}{2002} & \multicolumn{2}{|c|}{2006} \\
\hline & Export & Import & Export & Import & Export & Import \\
\hline Angola & 139.7 & 40.2 & 988.2 & 67.4 & $9,937.1$ & 983.8 \\
\hline Ethiopia & 0.7 & 67.5 & 7.4 & 144.4 & 119.8 & 474.8 \\
\hline Ghana & 7.7 & 122.5 & 27.4 & 200.5 & 72.6 & 883.2 \\
\hline Kenya & 1.3 & 68.3 & 4.7 & 76.8 & 22.1 & 683.8 \\
\hline Mozambique & 0.0 & 12.7 & 6.9 & 16.5 & 32.9 & 76.5 \\
\hline Nigeria & 24.9 & 393.1 & 73.9 & 739.2 & 252.5 & 3141.2 \\
\hline Senegal & 3.2 & 28.6 & 8.6 & 44.8 & 9.2 & 153.4 \\
\hline South Africa & 168.1 & 854.6 & 447.8 & $1,488.1$ & $2,085.1$ & $7,494.8$ \\
\hline Sudan & 1.3 & 384.5 & $1,052.1$ & 431.5 & $1,764.9$ & $1,558.5$ \\
\hline Zambia & 0.9 & 6.7 & 3.4 & 28.1 & 380.7 & 83.6 \\
\hline Zimbabwe & 16.6 & 50.7 & 29.4 & 24.4 & 25.8 & 45.9 \\
\hline
\end{tabular}

Note. Source: Spring and Jiao (2008) adapted from original data in the DOT database of IMF (Retrieved from www.imf.org).

Table 4

Sectoral Distribution of China's Foreign Direct Investment Inflows to Africa (1979-2000)

\begin{tabular}{lcc}
\hline Sector/Industry & Number of projects & Investment value $(\mathrm{m} \$)$ \\
\hline Agriculture & 22 & 48 \\
Resource extraction & 44 & 188 \\
Manufacturing & 230 & 315 \\
Machinery & 20 & 16 \\
Home appliances & 35 & 25 \\
Light industry & 82 & 67 \\
Textiles & 58 & 102 \\
Other manufacturing & 34 & 66 \\
Services & 200 & 125 \\
Others & 3 & 6 \\
Total & 499 & 681
\end{tabular}

Note. Source: UNCTAD (2007) (The figures relate to the number of project approvals).

It was noted that exports from Africa to Asia grew annually by 14 percent between 1990 and 1994, and accelerated by 19 percent between 2000 and 2004 as shown in Table 3. Asia accounts for 27 percent of Africa's exports, an amount that is almost equivalent to EU (32 percent) and US (29 percent) shares of Africa's exports. However, despite this growth, Africa's exports still remain relatively small, accounting for only 1.6 percent of Asian global imports (Rotberg, 2008). Conceivably, Africa's trade with China is expanding progressively largely because of China's demand for natural resources, and partly because of their industrial advantage in manufactured products. Indeed, the growth in Sino-African commerce is also attributable to two complimentary 
factors: Africa's endowments of natural resources and China’s skilled manpower.

Evidently, Chinese biggest investment in sub-Saharan Africa is in commodities, and to some extent, in other industries such as clothing, agriculture, electricity generation, road building, tourism, and telecommunication (Broadman, 2007; Anshan, 2006). Despite of indications recent studies that Chinese investment diversification in Africa (exporting, importing, wholly owned enterprises, franchising, and licensing) is also a relatively recent turn of events, Table 4 shows that it is not a new phenomenon. In terms of the number of Chinese investment projects in Africa, manufacturing industry has always been the most important sector.

\section{Cost-Benefit Analysis: Discussion of Benefits to Africa}

China and Africa have attracted each other intellectually, culturally, and commercially as early as the T'ang dynsasty (Broadman, 2008). Over time, China has become the largest investor, trader, importer, exporter, and aid donor in a number of strategic African countries, and a major new economic force in the entire sub-Saharan Africa. Before the turn of the 21st century, China supported and financed a number of anti-colonial liberation movements with their sophisticated weapons, arms, training, and funds. Political analysts indicate that in the final years of the twentieth century, China and Russia provided far more weapons to sub-Saharan African than did other industrialized nations, including the United States. For example, China single-handedly constructed arms factories in the Sudan and Uganda. Their equipment fueled both sides of the Ethiopian-Eritrean war, assisted the air force of Zimbabwe, and euippped the armies of over a dozen sub-Saharan nations (Bonga-Bonga, 2006; Alden, 2007; Broadman, 2008). China has been involved in the education of many African students by providing scholarships and encouraging different kinds of exchange programs. African citizens have benefited immensely from China-organized seminars, training courses, and symposia concentrated on such fields as management capabilities, engineering skills, and school administration. In his recent assessment, Broadman (2007) pointed out that China's Ministry of Education (MOE) developed courses at local universities for African teachers, engineers, and professionals. From 2002 to 2006, Jilin University trained 225 Africans in long-distance education. Similarly, Northeastern Normal University established a base for training Africans, and has completed nine seminars for more than 200 administrators from more than thirty African countries.

\section{Costs-Benefit Analysis: Discussion of Costs to Africa}

The expansion of world trade in the past few years as a result of globalization trend is endangering the economies of developing nations of Africa. It seems that the disadvantages of globalization outweighed its benefits in analyzing the situation in developing nations. Broadman (2007) argued that the presence of China in Africa has compounded economic and social problems in the continent. Furthermore, domestic businesses have been placed in a competitive disadvantage by the uncontrolled and unregulated Chinese presence in the market-place. Imported Chinese made brands are inferior and have displaced indigenous products. This saturation of African markets with Chinese made goods has created serious economic hardships, largely because of unfair competitive standards established for Sino-African trade relations. Unemployment, which is the immediate outgrowth of China's unabated presence and dumping, has reached disturbing and unprecedented proportions, and businesses are closing down in many African cities. As recent studies (Taylor, 2009; Rotberg, 2008; Alden, 2007) have determined, large Chinese state-owned corporations contract with governments and 
focus on construction projects and infrastructure maintenance, heavy industry (oil drilling and logging), and telecommunications. Over 800 of these projects were established in Africa around 2006 and were increasingly staffed with Chinese workers. Some of them were African contracted projects, while others were Chinese development aid projects financed by China's central and provincial governments, who were paid with African resources. A study by Taylor (2009) noted that a common complaint against Chinese companies, echoed by local business-owners interviewed in Botswana, Ethiopia, Namibia, Nigeria, Sierra Leone, and Uganda, was that they received preferential treatment from African governments, which places Chinese businesses at a competitive advantage. Indeed, a disgusted Nigerian local businessman complained that Chinese traders get explicitly favorable treatment, concessions, and privileges from governments (Spring \& Jao, 2008). This unbridled appeasement of Chinese competitors in Africa has become a major source of frustration to local enterprises, to the extent that many of them can no longer sustain their business operations.

The continuing growth of Sino-African trade relations has been characterized in negative terms and blamed for numerous human rights abuses in the region. Some African authors have been critical of Chinese's role in the liquidation of local businesses and outraged by their mistreatments of African citizens. A few selected statements from some African news sources indicate a range of discontentment with China's disregards for human rights. For example, Taylor (2009) observed that China is sacrificing human-rights protection for natural resources. The author added that unlike western countries which prohibit their corporations from doing business with renegade regimes, China encourages and supports dealing with Africa's most brutal and corrupt governments. In other words, China conducts business with governments in the sub-Saharan regardless of human-rights abuse and undemocratic activities, thereby undermining citizens' constitutional rights and good governance. Describing Africa's leadership as dictators, Spring and Jiao (2008) stressed that the governments viewed their partnerships with China as a strategic and reciprocal business venture. Also, Ngome (2007) and Spring (2008) noted the negative reactions of many Africans about the misguided rhetoric of their leaders, who encouraged collaborations with China. A recent survey in Cameroon showed the consternation, frustration, and sadness of the citizens. Alden (2007) described African governments with differing relationships to China as weak democracies with commodity-based economies and democracies with diversified economies, and concluded that the elites and government officials in these African nations (Angola, Chad, Nigeria, Cameroon, and Zimbabwe) enriched themselves through unethical business agreements with China.

\section{Policy Implications}

Sino-African trade prospered rapidly over a number of years largely because of the high demand for natural resources by China and its industrial advantage in manufactured products against sub-Saharan African countries. The growth is also attributable to the complementary situation between African countries and China based on the endowment of natural resources in Africa versus skill manpower in China (Broadman, 2008; Taylor, 2009). While this complementary development appears seemingly beneficial to the bilateral trade, important that African countries engage in a sustainable strategic plan that will leverage the current export-boom revenue in order to create opportunities for long term economic benefits through export diversification.

Understandably, participation in global markets will continue to enrich the economic development of Africa, but there is an urgent need to control excessive importation of goods and services from China. It is 
counter-productive to eliminate tariffs, quota, and quality control measures in any bilateral trade agreement, because it engenders the degree of market saturation that ultimately undermines long-term productivity of local enterprises. Further, it is important that African leadership provides adequate financial resources and protective measures for infant industry. African governments should engage in market negotiations with China based on the principle of comparative or absolute advantage. Indeed, a more realistic approach for Africa is to limit the quantity of importation of Chinese goods, and to encourage domestic businesses in order to ensure employment and sustainable economic advancement. As Oyewole and Okoro (2008) suggested, sub-Saharan region should raise its tariffs to get higher net barter in terms of trade and then increase its trade volume (imports plus exports) in order to take advantage of favorable terms of trade. African countries, especially the sub-Saharan region, should export more goods in order to gain from trade surplus.

\section{Conclusion}

Although China's policy toward Africa indicates a new type of strategic bilateral trade agreement, including the complete plan of the orientation and priorities for Sino-African friendship and cooperation, research evidence indicates an imbalance in their economic and financial relationships. Without a doubt, there is an increasing rejection of the deployment of China's workers in many areas of Africa, the unregulated importation of China's goods and services in the markets, which has been stifling domestic industries. As noted by researchers (Rotberg, 2008; Rudra, 2008; Taylor, 2009), sub-Saharan Africa has become an investment destination in the twenty-first century's globalized economy in which China is exploiting in order to sustain its marketing and business empire.

\section{References}

Alden, C. (2007). China in Africa. London: Zed Books.

Anshan, L. (2006). China-African Relations in the Discourse on China's Rise. Journal of World Economics and Politics, 11, 7-14. Bhargave, V. (2006). Global issues for global citizens: An introduction to key development challenges. Washington, D.C.: The World Bank.

Bonga-Bonga, L. (2006). Can China help revive the african textile industry? Univers: Foreign Affairs, December 7, 2.

Broadman, D. (2007). Africa's silk road. Washington, D.C.: The World Bank.

Center for Africa Studies of Peking University. (Ed.). (2005). China-Africa education cooperation (pp. 12-22). Beijing.

Chan-Fishell, M. (2007). Environmental impact: More of the same? In F. Manji, \& S. Marks (Eds.), African perspectives on China in Africa (pp. 139-154). Cape Town: Fahamu.

Corporate Council on Africa. (2001). Doing business with Africa. Washington, D.C.: Business Books International.

Devarajan, S., Dollar, D. R., \& Holmgren, T. (2001). Aid and reform in Africa. Washington, D.C.: The World Bank.

French, H. W., \& Polgreen, L. (2007, August 18). Entrepreneurs from China flourish in Africa. New York Times.

Gong, S. (2007). Chinese workers in Africa. Retrieved from http://www.globalization-africa.org/papers/80.pdf

Gyimah-Boadi, E. (2004). Democratic reform in Africa: The quality of progress. Boulder, C.O.: Lynne Rienner Publishers.

Lyman, P. (2005). China's rising role in Africa. Presentation to the US-China commission. Washington, D.C., July 21.

Oyewole, P., \& Okoro, E. (2008). Who pays more in the international market? An examination of terms of trade and tariffs of the countries of Africa. Innovative Marketing, 4(3).

People's Daily. (2007). China's African policy. Retrieved from http://English.peopledaily.com.cn/200601/12/print20060112_234894.html

Rotberg, R. I. (2008). China into Africa: Trade, aid, and influence. Washington, D.C.: The Brookings Institution.

Roughneen, S. (2006). Influence anxiety: China's role in Africa. ISN Security Watch, May 155, pp. 1-4.

Rudra, N. (2008). Globalization and the race to the bottom in developing countries: Who really gets hur? New York: Cambridge University Press. 
Spring, A. (2008). The west African enterprise network: Business globalists, interregional trade and U.S. interventions. In A. Jalloh, \& T. Falola (Eds.), The United States and West Africa: History, policy and business relations. Rochester: University of Rochester Press.

Spring, A., \& Jao, Y. (2008). China in Africa: African views of Chinese entrepreneurship. International Association of African Business Development Conference. Gainesville: University of Florida.

Spring, A., \& McDade, B. (1998). African entrepreneurship: Theory and reality. Gainesville: University of Florida Press.

Stiglitz, J. (2003). Globalization and its discontents. New York: W. Norton Company.

Taylor, I. (2009). China's new role in Africa. Boulder, C.O.: Lynne Rienner Publishers.

The Corporate Council on Africa. (2000). Doing business with Africa. Business Books International. New Canaan: CT.

Tull, D. M. (2006). China's engagement in Africa: Scope, significance and consequences. Journal of Modern African studies, 44(3), 459-479.

Wang, J. Y. (2007). What drives China’s growing role in Africa? International Monetary Fund (IMF) Working paper.

Wenzhong, Z. (2008). Ambassador extraordinary and plenipotentiary of the People's Republic Of China to the United States.

China-Africa Conference. Challenges and the Quest for Viable, Peace, Stability, and Development. Howard University, Washington, D.C. (March 31, 2008-April 1, 2008).

World Bank. (2006). World development indicators. Washington, D.C.: The World Bank.

World Bank. (2007). World development indicators. Washington, D.C.: The World Bank.

World Bank. (2008). World development indicators. Washington, D.C.: The World Bank.

Zafar, A. (2007). The growing relationship between China and sub-Saharan Africa: Macroeconomic, trade, investment, and aid links. The world Bank Research Observer, 22(1). 